Wilhelm Peekhaus:

\title{
A Marxist Account of and Suggested Alternative to Capitalist Academic Publishing
}

\begin{abstract}
:
This paper examines and situates theoretically from a Marxist political economic perspective the capitalist model of academic publishing using Marx's concepts of 'primitive accumulation' and 'alienation.' Primitive accumulation, understood as a continuing historical process necessary for capital accumulation, offers a theoretical framework to make sense of contemporary erosions of the knowledge commons that result from various enclosing strategies employed by capitalist academic journal publishers. As a theoretical complement, the article further suggests that some of the elements of alienation Marx articulated in respect of capitalistcontrolled production processes capture the estrangement experienced by the actual producers of academic publications. After offering a short assessment of the open-access movement as a remedial response to the enclosing and alienating effects inherent in the capitalist-controlled academic publishing industry, the article briefly outlines a suggested alternative model for academic publishing that, building on open-access projects, could radically subvert capitalist control.
\end{abstract}

\section{Agenda:}

Introduction

A Brief Outline of the Capitalist Academic Publishing Industry

Conceptualising Capitalist Control of Academic Publishing through the Lenses of Primitive Accumulation and Alienation

Open Access as a Response to Capitalist Control of Academic Publishing?

\section{Author(s):}

\section{Dr. Wilhelm Peekhaus:}

- School of Information Studies, University of Wisconsin-Milwaukee, 2025 E Newport, Northwest Quad, Bldg. B, 3rd Floor, Milwaukee, Wisconsin, USA 53211

酉 + $01-414-229-5033, \triangle$ peekhaus@uwm.edu

- Relevant publications:

- Resistance Is Fertile: Canadian Struggles on the Biocommons. Vancouver: University of British Columbia Press, 2013.

- Conceptualising and subverting the capitalist academic publishing model. In: C. Fuchs \& V. Mosco (Eds.), Marx and the political economy of the media (pp. 363-406). Leiden, Netherlands: Brill, 2016.

- How library and information science faculty perceive and engage with open access." Journal of Information Science, 41, 640-661. 


\section{Introduction}

"It becomes the task of science to be a means for the production of wealth; a means of enrichment ... science appears as a potentiality alien to labour, hostile to it and dominant over it."

Already a century and a half ago, Marx registered the expanding capitalist appropriation of science and other abstract knowledge that are constitutive of what he referred to as the general intellect. Although Marx was illuminating the appropriation of science from direct producers in service of capitalist accumulation imperatives within the factory and how the various forms of abstract knowledge encapsulated in the collective social intelligence of the general intellect were being objectified in the fixed capital of machinery, his basic argument is applicable to the contemporary capitalist scholarly communication industry; a multi-billion dollar industry in which majority control is exercised by a handful of publishing giants that exploit the free labour of academics and lockdown content through strict application of copyright and licencing restrictions in order to extract monopoly rents from institutions of higher education.

In response to the call informing this special issue about information ethics from a Marxian perspective, this article illustrates briefly and situates theoretically the contemporary capitalist model of academic publishing using Marx's concepts of 'primitive accumulation' and 'alienation.' Drawing mainly on Volume I of Capital, my goal is to demonstrate that primitive accumulation, understood as a continuing historical process necessary for capital accumulation, offers an apropos theoretical lens through which to contemplate contemporary erosions of the knowledge commons that result from various enclosing strategies employed by capitalist academic journal publishers. As a theoretical complement, I will further suggest that some of the elements of alienation Marx articulated in respect of capitalist-controlled production processes capture the estrangement experienced by the actual producers of academic publications. The exegetical account of alienation offered here relies primarily on Marx's discussion in the Economic and philosophical manuscripts. Following an assessment of the capitalist academic publishing system using this theoretical framework, the article then briefly critiques the current open-access regime and proposes an alternative system of academic publishing.

\section{A Brief Outline of the Capitalist Academic Publishing Industry}

Similar to other information and communication sectors, the academic publishing industry has experienced significant levels of consolidation over the past two decades, with the field now dominated by ten major corporations. The top three publishers of scientific journals (Elsevier, Springer, and Wiley-Blackwell) account for approximately $42 \%$ of all articles published. Although, according to Campbell, ${ }^{2}$ scholarly societies own and control approximately half of all peer-reviewed journals, no other publisher beyond the big three accounts for more than a three percent share of the journal market. ${ }^{3}$ In part, this concentrated degree of control has been made possible because these large capitalist publishers have been very successful in acquiring many of the most prestigious and high-circulation journals across almost all academic disciplines.

In addition to an increasingly consolidated industry, there are structural characteristics specific to the market for journal articles of which capital is able to avail itself in asserting its grip on academic publishing. ${ }^{4}$ One

\footnotetext{
1 Marx, Karl: Economic Manuscript of 1861-63. 32, 34 (emphasis in original)

2 Campbell, Robert: Overview of Academic and Professional Publishing.

3 McGuigan, Glenn and Robert Russell: The Business of Academic Publishing.

4 I would like to clarify my use of the term 'capital.' My intent is not to hypostatise 'capital' as a monolithic entity that develops and executes an internally consistent program of accumulation. Instead, I employ 'capital' as shorthand for the aggregation of individual
} 
particularly potent mechanism of control is the almost universal practice among capitalist journal publishers of making publication of scholarly articles contingent upon the author agreeing to transfer the intellectual property rights in a work to the publisher.

The nature of academic scholarship has also contributed to the power of capital. Unlike typical goods, competing journals and journal articles, although often complementary because of overlapping subject areas, are rarely substitutes for one another. This lack of fungibility substantially augments the monopoly power of publishers, particularly those that control the top-ranked journals in their respective fields, because academic library collection development policies are driven by the underlying objective to maintain and expand research holdings, which motivates collection development librarians to subscribe to as many of the key journals of record as is fiscally possible. Indeed, because of pressure from faculty to ensure easy access to key disciplinary journals, demand is relatively price-inelastic and differences in quality across journals are not typically reflected in price differentials. Cognisant of this captured market situation, publishers engage in profit maximising behaviour, such as price increases far in excess of inflation. ${ }^{5}$

Industry consolidation, working in tandem with the captured demand side of the market, gave rise to what is commonly referred to as a 'serials crisis,' which is shorthand for a double-pronged dilemma faced by academic libraries beginning in the 1990s: skyrocketing journal prices coupled with static or declining library budgets. Even in the most recent years following the global economic meltdown of 2008 , serials prices rose at rates between four and five percent, well above the negative average rate of inflation in 2009 and the $1.64 \%$ average level of inflation in 2010 in the United States. ${ }^{6}$ According to EBSCO, between 2007 and 2011 journal prices increased by almost 30\% for U.S.-based titles and almost 34\% for non-U.S. titles. ${ }^{7}$ Serials prices increased, on average, by another $6 \%$ each year between 2012 and 2016 . This compares to average United States consumer price inflation rates of $2.07 \%, 1.47 \%, 1.62 \%, 0.12 \%$, and $1.26 \%$ over the same years, meaning that journal prices have continued to far outpace both library budgets, which remain relatively flat, and broader levels of consumer price inflation. ${ }^{8}$ Average journal price increases for 2017 are forecasted to continue this trend and remain between $5 \%$ and $6 \% .^{9}$

capitalists who, in general, represent a class in the broader system of capitalist social relations. Along similar lines, and taking a cue from Massimo De Angelis (2007), who himself follows Marx's usage of the term, I will avoid the ism of 'capitalism' and instead discuss 'capital,' 'capitalist production relations,' and 'capitalist social relations.' Indeed, Marx talked about the capitalist mode of production rather than 'capitalism.' By adopting this perspective, Marx was in a position to develop a critique of capital as an all-encompassing social relation or, what Mészáros $(2008,75)$ refers to, as a system of social metabolic control: "Capital is not simply a material entity. We must think of capital as a historically determinate way of controlling social metabolic reproduction. That is the fundamental meaning of capital." Such a conceptualisation permits us to apprehend capital, or a capitalist mode of production, as one mode of organising livelihoods that co-exists with, and is related to, others. In this way, we can conceive of the social field as a space open to strategic contestation among different social forces.

5 Bergman, Sherrie: The Scholarly Communication Movement.

McCartan, Patrick: Journals and the Production of Knowledge.

6 Bosch, Stephen, Kittie Henderson, and Heather Klusendorf: Periodicals Price Survey 2011.

7 EBSCO: Five Year Journal Price Increase History (2007-2011).

8 These figures are the average of the 12 monthly inflation rates of each calendar year (http://www.inflation.eu/inflation-rates/unitedstates/historic-inflation/cpi-inflation-united-states.aspx).

9 Bosch, Stephen, and Kittie Henderson: The Winds of Change.

Bosch, Stephen, and Kittie Henderson: Steps Down the Evolutionary Road.

Bosch, Stephen, and Kittie Henderson: Whole Lotta' Shakin' Goin' On.

Bosch, Stephen, and Kittie Henderson: Fracking the Ecosystem.

Bosch, Stephen, and Kittie Henderson: New World, Same Model.

Bosch, Stephen, Kittie Henderson, and Heather Klusendorf: Periodicals Price Survey 2011. 
Given the space limitations of this journal, the foregoing sketch of the capitalist academic publishing industry has had to be extremely brief. Nonetheless, this outline highlights the extent to which academic publishing is increasingly subsumed within the capitalist mode of production. The following section of the article seeks to demonstrate that Marx's concepts of primitive accumulation and alienation provide apposite theoretical lenses through which to make conceptual sense of this situation.

\section{Conceptualising Capitalist Control of Academic Publishing through the Lenses of Primitive Accumulation and Alienation}

Marx provides his deepest discussion of primitive accumulation in Volume I of Capital, where he develops a critique of the 'so-called primitive accumulation' articulated by classical political economists. As Marx is at pains to point out throughout his work, capital must not be simply equated with a particular stock of wealth but must instead be understood as a social relation. Wealth is certainly a necessary precondition but by itself is not sufficient to explain the emergence of capitalist social relations. According to Marx, the appearance of capitalist social relations must be traced to the transformation of social property relations, which facilitates the translation of wealth into capital. ${ }^{10}$ At its most basic, primitive accumulation can be understood as providing the origin of the separation between producers and the means of production that characterises capitalist social and production relations. Primitive accumulation thus represents an historically specific and class-differentiated relationship of control over the necessary means of social production.

Most contemporary scholars engaging in a re-invigoration of primitive accumulation as a theory for comprehending contemporary capitalist development tend to agree on three additional basic points about this concept. ${ }^{11}$ First, primitive accumulation should be understood as a continuous process that remains vital for capitalist accumulation. As Marx informs us,

"the capital-relation presupposes a complete separation between the workers and the ownership of the conditions for the realization of their labour. As soon as capitalist production stands on its own feet, it not only maintains this separation, but reproduces it on a constantly expanding scale. "12

That is, the separation between producers and the means of production, a central category of Marx's critique of political economy, is the constitutive presupposition of accumulation and thus common to both primitive accumulation and accumulation in general - capital presupposes this separation. In Marx's own words,

"the manner in which the capitalist mode of production expands (takes possession of a greater segment of the social area) and subjects to itself spheres of production as yet not subject to it ... entirely reproduces the manner in which it arises altogether."13

\footnotetext{
${ }_{10}$ Marx, Karl: Capital, Vol. I.

11 Depending upon the theorist to whom one refers, the nominal term employed to reflect the phenomenon of primitive accumulation differs. Glassman (2006) discusses 'primitive accumulation,' 'accumulation by dispossession,' and 'accumulation by extra-economic means,' though he seems to favour the original term coined by Marx. McCarthy (2004) speaks of accumulation by 'extra-economic means.' Bonefeld $(2001,2002)$ and De Angelis $(2001,2007)$ remain true to Marx. Harvey $(2003,2006)$ prefers to substitute the expression 'accumulation by dispossession' for what he believes is the dated 'primitive accumulation.'

12 Marx, Karl: Capital, Vol. I. 874

13 Marx, Karl: Economic Manuscript of 1861-63. 327 (emphasis in original)
} 
Thus, once produced, capital must reproduce the separation between producers and the means of production (and, indeed, expand this reproduced separation to additional forms of social labour). We thus note that Marx's discussion of primitive accumulation contains a basic ontological connection between primitive accumulation and expanded reproduction, such that accumulation, in general, represents a form of intensified primitive accumulation. ${ }^{14}$

The second additional point about primitive accumulation is that it manifests itself in a variety of forms, including the privatisation of once public goods, which has the ultimate effect of re-organising class relations in favour of capital. The public good character of academic research and its dissemination has been transformed through extensive enclosing practices into a relatively new source of capital accumulation. The third additional feature of primitive accumulation speaks to its spatial ambition. Despite a general ethnocentrism present in Marx's work (an ethnocentrism that Marx readily admits), he discusses both the historical and the global elements of the processes of primitive accumulation, through which a privileged minority relentlessly pillaged the means of production from the people of pre-capitalist civilisations around the world:

"The discovery of gold and silver in America, the extirpation, enslavement and entombment in mines of the indigenous population of that continent, the beginnings of the conquest and plunder of India, and the conversion of Africa into a preserve for the commercial hunting of blackskins, are all things which characterize the dawn of the era of capitalist production. These idyllic proceedings are the chief moments of primitive accumulation. ${ }^{15}$

Ensuring an expanded reproduction of capital depends upon enveloping new spheres of production and peoples within the web of capitalist social relations of (re)production. Having historically extended the territorial reach of capitalist social relations through colonialist expansion and the imposition of private property rights across the globe, primitive accumulation in the twenty-first century has become both more extensive and intensive, affecting an ever-increasing range of social activity. In practice, primitive accumulation motivates efforts by capital to enclose more and more areas of our social existence that can be mined for extraction of surplus value. Thus, primitive accumulation processes of enclosure all share the basic universal character of separating people from access to any social wealth that falls outside the purview of competitive markets and money as capital. That is, in line with the elaboration above about the basic element of the theory of primitive accumulation, enclosures provide a mechanism for realising the ex novo separation between producer and the means and objects of production. ${ }^{16}$

This separation is responsible for the alienated character of labour and thus for defining the opposition inherent in capitalist social relations. As articulated most fully in the Economic and philosophical manuscripts, the alienation of labour under capitalist social relations manifests itself in four ways, two of which are most germane to the present work. ${ }^{17}$ The first consequence of the estrangement of practical human activity - of labour - is

14 Bonefeld, Werner: The Permanence of Primitive Accumulation.

Bonefeld, Werner: History and Social Constitution.

De Angelis, Massimo: Marx and Primitive Accumulation.

De Angelis, Massimo: The Beginning of History.

Mandel, Ernest: Late Capitalism.

15 Marx, Karl: Capital, Vol. I. 915

16 De Angelis, Massimo: The Beginning of History.

Harvey, David: The New Imperialism.

Harvey, David: Spaces of Global Capitalism.

17 In elaborating his third characteristic of capitalist alienation, Marx contemplates the effects of alienation on the person's relationship to other people when engaging in productive activity, itself a fundamentally social activity. The fourth type of alienation that Marx 
a resulting alienated relationship between the worker and the product of labour, which, because of private property and the capital-labour relation, appears as something alien - as a power independent of the actual producer. Since the product of the worker's labour is an alien object that belongs to the capitalist paying her wage, the more that she toils under capitalist social relations the more powerful becomes the alien, objective world she brings into being against herself. Although this basic idea inheres in the production of academic journal articles, it does require a slight adaptation. Publishers own the means of dissemination not production, as is the more traditional Marxist understanding of the alienation inherent in capitalist social relations premised on wage labour. Although an argument could be made that, because journal content is a necessary factor of production in subsequent research, the capitalist ownership of such content represents partial capitalist control of the means of production. In any event, the perhaps stronger argument is that this type of control facilitates an even more insidious form of exploitation and alienation since capitalist publishers provide neither a wage nor the means of production (in the strictest sense), yet accumulate the benefit of the product of intellectual labour. At an even more fundamental level, an argument could be advanced that, from Marx's dialectical perspective, alienation reaches farther back than the estrangement of direct producers from the means of production and the resulting products of social labour to include the alienation inherent in the disconnect between the driving motivation of capital, the profit motive, and the fulfilment of socially-produced human needs, including those for research and knowledge. ${ }^{18}$

A second, and related, aspect of the alienation of labour encompasses the relationship of the worker to the act of production within the labour process. Under the control of capitalist production processes, not only is the product of labour objectified in an alien object that holds power over the actual producer, but the corresponding form of productive activity renders the worker's own labour as something alien and opposed to him, reflecting an estrangement from himself and from his own activity. Rather than offering satisfaction in and of itself, alienated labour is external to the worker, something sold to and thus belonging to someone else. Through its alienability, the relationship of the worker to her activity becomes an example of what Marx refers to as 'selfestrangement':

"... estrangement manifests itself not only in the result, but also in the act of production, within the activity of production itself. ... So if the product of labour is alienation, production itself must be active alienation, the alienation of activity, the activity of alienation. The estrangement of the object of labour merely summarizes the estrangement, the alienation in the activity of labour itself."19

Under the dominance of capitalist social relations, we witness the social separation of the conditions of production from the control of the direct producers. This dual form of alienation inheres in the scholarly communication process that is dominated by commercial publishers, who have been quite successful in wresting the outputs of scholarly research from the control of direct producers in service of capitalist accumulation imperatives.

\section{Capitalist Academic Publishing as an Alienating Instance of Primitive Accumulation}

Recognising new opportunities for accumulation associated with the burgeoning volume of journals and research articles being produced by academics, capital began exerting a stranglehold over this industry and the processes of scholarly communication in what can be interpreted as yet another area of social existence now

develops in the Economic and philosophical manuscripts is the notion of alienation from species-being - alienation from a person's being as a member of the human species.

18 Burkett, Paul: Marx and Nature.

Mandel, Ernest: Marxist Economic Theory.

19 Marx, Karl: Economic and Philosophical Manuscripts. 326 (emphasis in original) 
brought under capitalist control, thus reinforcing the idea that primitive accumulation remains a continuous social process. ${ }^{20}$ By appropriating the free labour that sustains the production, peer review, and editing of scholarly research and then locking the resulting content behind intellectual property rights, licencing agreements, and technological protection mechanisms, capital has developed a very lucrative model of value extraction in service of its own accumulation imperatives. Put another way, capitalist academic publishing is premised on the private expropriation of much of the value that is produced in common through the cooperative relationships inherent in scholarly research production.

The result of these processes is an increasing individuation and alienation of scholarly producers that dispossesses them of their material capacity to consciously control their product and potentially their labour processes. While there might not be a formal separation of academic producers from the most basic means of production, the dissemination and use of the products of research production are subsumed increasingly within capitalist modes of production and exchange. This intensifying enclosure of academic publishing within the capitalist market nexus that is informed by property rights, alienability, and capital accumulation represents a contemporary instance of primitive accumulation and alienated productive activity.

Capitalist control of academic publishing industry is similarly testament to the expanding range of actors caught up in practices of primitive accumulation and capitalist control of social production processes. The increasing integration of academic journal publishing into capitalist relations of production and exchange similarly demonstrates how contemporary processes of primitive accumulation and the consequent expanding capitalist control of social production processes are exacerbating the alienation Marx elaborated to include new strata of producers beyond the orthodox Marxist emphasis on the industrial proletariat and waged labour. That is, despite a still relatively privileged position vis-à-vis other workers (albeit one increasingly under attack), it is precisely through such capitalist-controlled processes that cognitive workers in the academy are being caught up within and subject to some of the constraining and exploitative practices of capitalist accumulation processes.

However, the imposition of an ex novo separation of the conditions of production from the control of the direct producers represents a social process that is susceptible to contestation by oppositional social forces seeking to recover those social spaces appropriated by capital and to re-invigorate them as spaces of commons. Capital is thus compelled to wage a two-front war in its battles for enclosure: invading and enclosing new realms of social existence that can be subverted in service of capital's accumulation priorities, and defending those enclosed areas governed by commodification and accumulation imperatives against ex novo guerrilla movements struggling to liberate enclosures from capitalist control. ${ }^{21}$ Enclosures, and the resistance they engender, thus represent strategic problems for capital. Such resistance poses limits that must be overcome if capital is to be successful in colonising new areas of social existence or in sustaining those areas already enclosed from attacks by alternative social forces seeking to de-commodify and transform them into commons. Very much aligned with Marx's dialectical method, we thus note that commons can emerge out of struggles against their negation.

20 The contemporary commercialisation of academic journal publishing has been traced to the 1946 launch of Biochimica et Biophysica Acta by Robert Maxwell, who built and later plundered a major publishing empire in the United Kingdom that began with academic publishing (Campbell 2012)

21 De Angelis, Massimo: The Beginning of History. 


\section{Open Access as a Response to Capitalist Control of Academic Publishing?}

In response to several of the trends in the academic publishing industry that have clearly disadvantaged both authors and libraries - that is, the producers and the purchasers of scholarly output - a sustained movement that advocates for and develops open-access models to academic research began emerging around the turn of the millennium. Open access refers to the free and unrestricted availability of scholarly literature on the Internet that people may access and use for any lawful purpose. The two major types of open access are gold and green. Gold open access refers to peer-reviewed publication in an open-access journal that does not levy subscription fees but may or may not require authors to pay article-processing fees. Green open access involves uploading the work to an institutional or subject electronic repository.

Research provides evidence that the gold model of open-access journal publishing has matured into a sustainable form of scholarly publication. ${ }^{22}$ In fact, a quick search of the Directory of Open Access Journals revealed over 9,400 registered journals as of June 2017. Further, albeit disconcerting, evidence of the growing sustainability of open-access publishing comes from a number of capitalist publishers, which have begun to offer open-access options to individual authors in what are otherwise subscription-based journals. In exchange for payment of an open-access publication fee typically in the range of US $\$ 2,000-$ US $\$ 3,000$, commercial publishers, such as Elsevier, Springer, Taylor \& Francis, and Sage, among others, provide electronic open access to the published version of an author's journal article. These hybrid models are especially lucrative for publishers since they are essentially paid twice for the same article, which is why this practice has come to be known colloquially as 'double dipping.'

Capitalist publishers have also adopted gold open-access models and now offer a large number of fully openaccess journal titles across an array of subject areas. Article-processing fees levied on authors vary widely by publisher and journal, from as 'little' as US $\$ 500$ to US $\$ 4,500$ or more. The fact that there is such a range of article-processing fees indicates that they are less a reflection of actual production costs and instead based more on a calculus of what the market will bear. Similar to the captured demand side of the market that offers publishers the opportunity to grossly inflate journal prices, at the production level a similar logic applies given that authors, or at least well-funded authors, will likely remit high fees to publish in high-impact journals.

What these brief examples clearly demonstrate is that open access per se is not inherently anti-capitalist and likely will not improve the long-term financial sustainability of the scholarly communication system or help the actual producers assert control over the system. Instead, these corporate adaptations to open access represent a direct response by capitalist publishers to subvert the open-access model in service of their own accumulation imperatives. Indeed, content delivery through the online open-access model contributes to publishers' profits by lowering marginal costs of production to almost zero and eliminating many of the traditional costs associated with physically publishing a paper journal (for example, materials, printing, inventory management, and distribution costs). Moreover, with funding agencies and universities beginning to apportion more funds to cover publication fees, there exists the potential for capitalist publishers to retain their control and their rentseeking behaviour as they shift their revenue models from being subscription-based to instead rely on author fees. Given the historically, often-successful ability of capital to decompose class struggle and re-appropriate for its own ends the creativity produced in common by autonomous workers, the increasing adoption of open- 
access models by capitalist publishers is a worrisome trend that demands a counter-response by the academic producers who sustain the scholarly communication system.

\section{A Suggested Strategy to Re-appropriate Academic Publishing}

As perhaps the first part of that response, we need to sharpen the distinction between open access that can be harnessed to serve capital, and explicitly anti-capitalist open access, in what we might term a commonsbased open-access regime that more accurately reflects the true nature of peer- and commons-based scholarly knowledge production. As mentioned previously, academics provide the majority of labour that sustains the production of scholarly knowledge, including the actual research and writing, peer review, and editing. It is time for academics to re-appropriate from capital the products and processes of their collective labour in order to revitalise the knowledge commons in ways that serve the public good rather than capitalist accumulation imperatives. I therefore suggest that we need to become more radical in our thinking and our actions in order to wrest control of academic publishing from the current capitalist oligarchs. And although this might require significant amounts of persuasion among some of our more conservative colleagues, I want to suggest that logistically such a re-appropriation would be less difficult.

There already exists a basic publishing infrastructure in the form of non-profit university presses, which should be able to substitute easily for capitalist publishers in ways that would not require the assignment of copyright by authors or the imposition of onerous pricing and licensing contracts on library customers. Indeed, university presses have substantial historical experience in facilitating the dissemination of scholarly research across multiple product lines (trade books, scholarly monographs, textbooks, and journals). Moreover, there is a variety of freely available, technologically sophisticated digital publishing platforms (for example, Open Journal Systems) that university presses could employ to produce electronic journals. I therefore contend that university presses are best positioned to fulfil the key aspects of the scholarly communication system in ways that would promote access, remedy the fiscal instability of the current capitalist-dominated model, and restore control to the actual producers and users of the system.

\section{Conclusion}

As elaborated above, Marx critiques capital as an alienating social form because it privatises the product of another's labour as property, thus rendering it susceptible to the exigencies of atomised market exchange from which an inequitable distribution of the wealth generated by social production obtains. The object of labour increasingly appears as alien property to the actual producers as the means of their existence and the products of their activity are concentrated progressively in the hands of capital. Capitalist control of academic publishing through strategies and practices such as industry consolidation and forced assignment of copyright represents a new modality of primitive accumulation that strives to appropriate and enclose the knowledge commons that otherwise would emerge from the unrestricted flow of academic research. That is, through such means of control, capital is able to appropriate for its own accumulation imperatives the massive amounts of 'free' labour that sustain the content production and evaluation elements of the academic journal publishing industry.

Yet, there is hope. The success of the open-access movement and models has demonstrated that there are viable alternatives to the capitalist control of academic publishing. However, the dominant open-access regime suffers from inherent neutrality in respect of economic model that renders it susceptible to capitalist appropriation and exploitation. I therefore suggested that we need to become even more radical in our solutions to the capitalist enclosure of our scholarly communication system. The requisite technological, logistical, and financial capacities exist for scholarly journal publishing to be reclaimed by members of the academy through their non-profit university presses. What remains to be effected is an awakening among producers and users of the scholarly communication system to the need to avail themselves of these capacities in order to exert autonomous self-control over this system that remains so vital to the research and educational missions of universities. 
If nothing else, my hope is that this article engenders further discussion, elaboration, and eventual implementation of strategies that return complete and common ownership of the products and processes of academic knowledge creation to the actual producers and users.

\section{References}

Bergman, Sherrie S. "The Scholarly Communication Movement: Highlights and Recent Developments." Collection Building 25 (2006): 108-28.

Bonefeld, Werner. "History and Social Constitution: Primitive Accumulation Is Not Primitive." The Commoner, no. March (2002): 1-8. http://www.commoner.org.uk/debbonefeld01.pdf.

- "The Permanence of Primitive Accumulation: Commodity Fetishism and Social Constitution." The Commoner 2, no. September (2001): 1-15. http://www.commoner.org.uk/02bonefeld.pdf.

Bosch, Stephen, and Kittie Henderson. "The Winds of Change: Periodicals Price Survey 2013." Library Journal 138 , no. 8 (2013): 28-33.

- . "Steps Down the Evolutionary Road: Periodicals Price Survey 2014." Library Journal 139, no. 7 (2014): 32-37.

—. "Whole Lotta' Shakin' Goin' On: Periodicals Price Survey 2015." Library Journal 140, no. 7 (2015): 3035.

—. "Fracking the Ecosystem: Periodicals Price Survey 2015." Library Journal 141, no. 7 (2016): 32-38.

—. "New World, Same Model: Periodicals Price Survey 2015." Library Journal 142, no. 7 (2017): 40-46.

Bosch, Stephen, Kittie Henderson, and Heather Klusendorf. "Periodicals Price Survey 2011: Under Pressure, Times Are Changing. "Library Journal 136, no. 8 (1 May 2011 2011): 30-34.

Burkett, Paul. Marx and Nature: A Red and Green Perspective. New York: St. Martin's Press, 1999.

Campbell, Robert. "Introduction: Overview of Academic and Professional Publishing." In Academic and Professional Publishing, edited by Robert Campbell, Ed Pentz and Ian Borthwick, 1-14. Oxford: Chandos, 2012.

De Angelis, Massimo. "Marx and Primitive Accumulation: The Continuous Character of Capital's "Enclosures"." The Commoner 2, no. September (2001): 1-22.

- The Beginning of History: Value Struggles and Global Capital. London: Pluto, 2007.

EBSCO. "Five Year Journal Price Increase History (2007-2011)." Ipswich, MA: EBSCO, 2011.

Glassman, Jim. "Primitive Accumulation, Accumulation by Dispossession, Accumulation by 'Extra-Economic' Means." Progress in Human Geography 30 (2006): 608-25.

Harvey, David. The New Imperialism. Oxford: Oxford University Press, 2003.

-. Spaces of Global Capitalism. New York: Verso, 2006.

Laakso, Mikael, Patrik Welling, Helena Bukvova, Linus Nyman, Bo-Christer Björk, and Turid Hedlund. "The Development of Open Access Journal Publishing from 1993 to 2009." PLoS ONE 6, no. 6 (2011): e20961. http://dx.doi.org/10.1371\%2Fjournal.pone.0020961.

Mandel, Ernest. Marxist Economic Theory. New York: Monthly Review Press, 1968.

- Late Capitalism. Translated by Joris De Bres. London, GB: NLB, 1975.

Marx, Karl. "Economic and Philosophical Manuscripts (1844)." Translated by Rodney Livingstone and Gregor Benton. In Early Writings, 279-400. New York: Vintage Books, 1975.

- Capital: A Critique of Political Economy. Translated by Ben Fowkes. Vol. I, London: Penguin Books, 1992.

. "Economic Manuscript of 1861-63 (Conclusion)." Translated by Ben Fowkes. In Karl Marx, Frederick Engels: Collected Works, 7-336. New York: International Publishers, 1994. 
McCartan, Patrick. "Journals and the Production of Knowledge: A Publishing Perspective." British Journal of Political Science 40 (2010): 237-48.

McCarthy, James. "Privatizing Conditions of Production: Trade Agreements as Neoliberal Environmental Governance." Geoforum 35 (2004): 327-41.

McGuigan, Glenn S., and Robert D. Russell. "The Business of Academic Publishing: A Strategic Analysis of the Academic Journal Publishing Industry and Its Impact on the Future of Scholarly Publishing." Electronic Journal of Academic and Special Librarianship 9, no. 3 (2008). http://southernlibrarianship.icaap.org/content/v09n03/mcguigan_g01.html.

Mészáros, István. The Challenge and Burden of Historical Time: Socialism in the Twenty-First Century. New York: Monthly Review Press, 2008. 